\title{
PRODUCTION AND STABILITY OF MYCO- FLOCCULANTS FROM LENTINUS SQUARROSULUS RWF5 AND SIMPLICILLIUM OBCLAVATUM RWF6 FOR REDUCTION OF WATER TURBIDITY
}

\author{
Nessa Jebun, Md. Zahangir Alam*, Abdullah Al-Mamun \\ AND RAHA AHMAD RAUS \\ Bioenvironmental Engineering Research Centre (BERC), \\ Department of Biotechnology Engineering, Faculty of Engineering, \\ International Islamic University Malaysia, \\ Jalan Gombak, 53100 Kuala Lumpur, Malaysia. \\ *Corresponding author: zahangir@iium.edu.my
}

(Received: $8^{\text {th }}$ May 2018; Accepted: $21^{\text {st }}$ Nov 2017; Published on-line: $1^{\text {st }}$ June 2018)

https://doi.org/10.31436/iiumej.v19i1.843

\begin{abstract}
The production and stability of two novel myco-flocculants produced by river water fungus (RWF) were investigated. Screening tests were conducted to find suitable nutrients, $\mathrm{pH}$, nutrient concentration, inoculum dose, and stability for two mycoflocculants $L$. squarrosulus (RWF5) and S. obclavatum (RWF6). The strains showed good flocculating activity in reducing turbidity of kaolin suspension while malt extract was used as nutrient source. Supernatants of RWF5 and RWF6 were able to reduce turbidity from $900 \pm 10 \mathrm{NTU}$ to $46 \mathrm{NTU}$ (95\%) and $195 \mathrm{NTU}$ (78\%), respectively. In order to enhance the production, optimization of cultivation conditions were studied using a one-factor-at-atime (OFAT) method. L. squarrosulus (RWF5) reduced $96 \%$ of turbidity at optimum conditions, comprising of $0.1 \%(\mathrm{w} / \mathrm{v})$ malt extract, $3 \%(\mathrm{v} / \mathrm{v})$ inoculum dose, and initial $\mathrm{pH}$ 7.0 for 6 days. The results of the compatible mixed culture showed good flocculation activity at $88 \%$ compared to a single culture of S. obclavatum at $78 \%$. On the other hand, L. squarrosulus showed better turbidity reduction in the single culture rather than the mixed culture. The stability of $L$. squarrosulus and $S$. obclavatum supernatants showed excellent turbidity reduction over a wide $\mathrm{pH}$ range of 4-8 with the maximal flocculation rate of $96 \%$ and $90 \%$, respectively, at $\mathrm{pH} 7.0$. They also exhibited high turbidity removal ability in a temperature range of $4{ }^{\circ} \mathrm{C}-55^{\circ} \mathrm{C}$ for $24 \mathrm{~h}$ with a maximum turbidity removal rate of $96 \%$ (RW5) and $87 \%$ (RW6) at $25{ }^{\circ} \mathrm{C}$. Time stability of the L. squarrosulus supernatant showed good turbidity removal potential at above $90 \%$ at room temperature $\left(28 \pm 2{ }^{\circ} \mathrm{C}\right)$ and $85 \%$ at low temperature $\left(4^{\circ} \mathrm{C}\right)$ for 12 days. The high flocculating rate of the myco-flocculants and their good stability under wide range of temperature indicated their potentiality as biodegradable flocculants for water and wastewater treatment industry.
\end{abstract}

ABSTRAK: Keberhasilan dan kestabilan dua myco-gumpalan baharu oleh kulat air sungai (RWF) telah dikaji. Ujian penapisan telah dijalankan untuk mencari nutrien sesuai, $\mathrm{pH}$, kepekatan nutrien, dos inokulum dan kestabilan dua myco-gumpalan L. squarrosulus (RWF5) dan S. obclavatum (RWF6). Rantaian menunjukkan aktiviti gumpalan yang baik dalam mengurangkan kekeruhan air sungai dengan penggantungan koalin di mana ekstrak malt telah digunakan sebagai sumber nutrien. Larutan supernatan RWF5 dan RWF6, masing-masing mampu mengurangkan kekeruhan dari 900 \pm 10 NTU kepada 46 NTU (95\%) dan 195 NTU (78\%). Bagi meningkatkan pengeluaran, keadaan optimum bagi menggalakkan hasil telah diselidiki menggunakan kaedah Satu Faktor pada Tiap Masa (OFAT). Pada takat optimum, L. squarrosulus (RWF5) mengurangkan 96\% kekeruhan, 
ianya terdiri daripada ekstrak malt $0.1 \%(\mathrm{w} / \mathrm{v})$, dos inokulum $3 \%(\mathrm{v} / \mathrm{v})$ dan $\mathrm{pH}$ awal 7.0 selama 6 hari. Keputusan kultur campuran yang sesuai menunjukkan aktiviti penggumpalan yang baik pada $88 \%$ berbanding kultur sendirian S. obclavatum pada $78 \%$. Pada waktu sama, $L$. squarrosulus menunjukkan pengurangan kekeruhan yang lebih baik dalam kultur sendirian berbanding kultur campuran. Kestabilan larutan supernatan $L$. squarrosulus dan $S$. obclavatum menunjukkan pengurangan kekeruhan yang sangat baik pada $\mathrm{pH}$ yang luas iaitu 4-8 dengan kadar maksimum kekeruhan pada $96 \%$ dan $90 \%$, pada pH 7.0 masing-masing. Keduanya menunjukkan kebolehan penyingkiran kekeruhan yang tinggi pada skala suhu $4{ }^{\circ} \mathrm{C}-55^{\circ} \mathrm{C}$ selama 24 jam dengan kadar nyah kekeruhan maksimum pada $96 \%$ (RW5) dan $87 \%$ (RW6) pada suhu $25^{\circ} \mathrm{C}$. Kestabilan masa larutan supernatan $L$. Squarrosulus menunjukkan potensi penyingkiran kekeruhan terbaik atas $90 \%$ pada suhu bilik $\left(28 \pm 2{ }^{\circ} \mathrm{C}\right)$ dan $85 \%$ pada suhu rendah $\left(4{ }^{\circ} \mathrm{C}\right)$ selama 12 hari. Kadar gumpalan yang tinggi oleh myro-gumpalan dan kestabilan yang baik pada julat suhu yang luas menunjukkan potensinya sebagai agen biodegradasi gumpalan kepada air dan industri rawatan loji air.

KEYWORDS: flocculation; jar test; Lentinus squarrosulu; mixed culture; Simplicillium obclavatu; stability; turbidity

\section{INTRODUCTION}

Chemical flocculants are widely used in wastewater and drinking water treatment, food and fermentation industries, as well as in downstream processing due to their high flocculating efficiency and cost-effectiveness. [1,2] Generally, flocculating agents that have the most usage in water treatment are the synthetic ones such as aluminium sulphate, ferric chloride, lime, and synthetic polymers. [3,4] Aluminium salts are the most widely used coagulant in water and wastewater treatment because of their proven performance and cost effectiveness. However, chemical coagulants cannot be easily degraded in nature and may result in various health and environmental problems. [5] Compared with chemical flocculants, bioflocculants have more advantages, such as being environmentally friendly due to their biodegradability, largely nontoxic with no secondary pollution, and harmless to both humans and animals. [6] Therefore, bioflocculants have recently gained global attention in research because they hold immense potential in replacing chemical flocculants. For example, Li et al. [7] reported that B. licheniformis produced ZS-7 bioflocculant is expected to be a potential replacement for conventional synthetic flocculants such as PAC (polyaluminum chloride) and PAM (polyacrylamide) for the treatment of low temperature and room temperature $\left(25^{\circ} \mathrm{C}\right)$ drinking water. Similarly, Gong et al. [8] reported Serratia ficaria produced bioflocculant SF-1 showed 91.8 - 93.7\% turbidity removal from wastewater, which is better than that of PAC and PAM. Aspergillus flavus produced IH-7 bioflocculant showed better flocculation performance than PAC and $\mathrm{IH}-7$ was significantly used to flocculate different types of suspended solids such as activated carbons, kaolin clays, soil solids, and yeast cells [9]. Moreover, bioflocculants are widely used for the recovery of suspended solids (SS) from wastewater treatment [10-12].

Bioflocculants are secondary metabolites produced during the growth of microorganisms such as bacteria, yeast and fungi that are composed of polysaccharides, proteins, lipids, glycoproteins, and glycolipids [13-15]. The composition and properties of coagulants depend on the type of flocculant-producing microorganisms (BPMs), composition of the media, and many conditions. The differences in the composition and properties of polysaccharides and proteins lead to differences in the charge of coagulant [16]. Culture conditions screening is a powerful approach to increase the production of extra polymeric substances from microorganism cultivation [17]. Although most flocculants can 
be used to flocculate kaolin suspension, they show different flocculating ability for other particles or colloids in aqueous solutions. Jebun et al. $[18,19]$ reported some filamentous fungi isolated from river water samples showed good entrapment potentiality to reduce turbidity from river water. Deng et al. [20] reported Aspergillus parasiticus produced a coagulant with high flocculating activity for kaolin suspension and water-soluble dyes. $\mathrm{Pu}$ et al. [21] reported that the compound coagulant produced by two strains of Rhizopus sp. was successfully used to reduce turbidity from potato starch wastewater. The same observation was made by Luvuyo et al. [22] for turbidity removal from kaolin clay by bioflocculant produced by a mixed culture of Methylobacterium sp. and Actinobacterium $s p$.

In the present study, we examine the suitable culture conditions for the production of myco-flocculants by two novel $L$. squarrosulus RWF5 and $S$. obclavatum RWF6 for reducing turbidity from synthetic turbid water. The screening tests were conducted to find suitable nutrients, $\mathrm{pH}$, nutrients concentration and inoculum size of these two potential fungi to enhance flocculation performance. In addition, stability of the single and compatible mixed culture supernatants (myco-flocculants) was investigated for chemical and environmental conditions to reduce turbidity by jar test.

\section{MATERIALS AND METHODS}

\subsection{Microorganisms and Growth Conditions}

L. squarrosulus RWF5 and S. obclavatum RWF6 were isolated from river water samples collected from the River Pusu on the IIUM campus for coagulant production. $L$. squarrosulus RWF5 and S. obclavatum RWF6 cultures were maintained on potato dextrose agar (PDA) (Oxoid, UK) and initial $\mathrm{pH}$ was adjusted to 5.8 \pm 0.2 . Distilled water was used to prepare medium solutions and sterilized at $121^{\circ} \mathrm{C}$ for 20 minutes. The culture plates were incubated at $32 \pm 2{ }^{\circ} \mathrm{C}$ for 10 days. Subculture was conducted twice in a month and sub culture plates were stored at $25^{\circ} \mathrm{C}$ in an incubator for further use.

\subsection{Myco-coagulants Production}

\subsubsection{Screening of Nutrients}

The screening medium consisted of $5 \mathrm{~g} / \mathrm{l}$ starch, sucrose, yeast extract, and malt extract and each of the medium was mixed with 1 liter of distilled water. The medium was then sterilized by autoclaving it at $121{ }^{\circ} \mathrm{C}$ for 15 minutes and then inoculated with $2 \%(\mathrm{v} / \mathrm{v})$ fungal mycelial inoculum $(340 \mathrm{mg} / \mathrm{l})$. The liquid culture was then incubated in a rotary shaker with agitation at $150 \mathrm{rpm}$ at $30 \pm 2^{\circ} \mathrm{C}$ for 8 days. Initial $\mathrm{pH}$ of the broth was adjusted at $7.0 \pm 0.1$ using $1 \mathrm{M} \mathrm{NaOH}$ or $2 \mathrm{M} \mathrm{HCl}$. Supernatants were taken at different time intervals to determine the flocculation activity. The effect of cultivation time for myco-flocculants production was investigated for 8 days.

\subsubsection{Factors Affecting the Flocculating Rate}

To study the effect of malt extract concentration of $0-1 \%(\mathrm{~g} / \mathrm{l})$, initial $\mathrm{pH}$ values of 5 , 6,7 , and 8 , and inoculum doses of $1-4 \%$ on the flocculating rate were investigated. In this experiment, OFAT analysis was followed for three factors such as media concentration, $\mathrm{pH}$, and inoculum dose.

\subsubsection{Single and Mixed Culture}

The production medium consisting of $5 \mathrm{~g} / \mathrm{l}$ malt extract was autoclaved at $121{ }^{\circ} \mathrm{C}$ for 15 minutes. The sterilized medium was inoculated with $2 \%(\mathrm{v} / \mathrm{v})$ fungal inoculum for single 
and mixed culture (mycelium concentration of $340 \mathrm{mg} / \mathrm{l}$ ). Ten day old culture plates were used to prepare fungal inoculum and the culture was incubated in a rotary shaker with 150 $\mathrm{rpm}$ at $30 \pm 2{ }^{\circ} \mathrm{C}$ for 6 days. Initial $\mathrm{pH}$ of the culture was adjusted at $7.0 \pm 0.1 \mathrm{using} 1 \mathrm{M} \mathrm{NaOH}$ or $2 \mathrm{M} \mathrm{HCl}$. The cultures were harvested after 6 days of treatment and centrifuged to separate the biomass from supernatant $\left(10^{3} \mathrm{rpm}\right.$ for $10 \mathrm{mins}$ at $\left.25^{\circ} \mathrm{C}\right)$. The supernatants were used as myco-flocculants and stored at room temperature at $28 \pm 2{ }^{\circ} \mathrm{C}$ for further use.

\subsection{Myco-flocculant Stability}

\subsection{1 pH Stability of Supernatants}

The $\mathrm{pH}$ of myco-flocculants from single and mixed cultures was adjusted to 4, 5, 6, 7, and 8 with $1 \mathrm{M} \mathrm{NaOH}$ and $2 \mathrm{M} \mathrm{HCl}$. A Jar test was conducted to observe flocculation activity in different $\mathrm{pH}$. Initial turbidity and $\mathrm{pH}$ of kaolin suspension were recorded at $900 \pm 10 \mathrm{NTU}$ and $7.0 \pm 0.1$, respectively and the mixture was stirred at $120 \mathrm{rpm}$ for 40 minutes and allowed to settle for 30 minutes.

\subsubsection{Temperature Stability}

Myco-flocculants were treated at different temperatures of 4, 25, 35, 45 and $55^{\circ} \mathrm{C}$ for 24 hours. Both supernatants were applied in kaolin suspension to reduce turbidity with the same conditions as referred to section 2.3.1.

\subsubsection{Time Stability of L. squarrosulus Produced Myco-flocculant}

The myco-flocculant produced by L. squarrosulus RWF5 was tested for flocculation activity capability. The myco-flocculant was kept in room temperature $\left(28 \pm 2{ }^{\circ} \mathrm{C}\right)$ and low temperature $\left(4^{\circ} \mathrm{C}\right)$ for 20 days. Jar tests were conducted to observe flocculation activity in terms of reducing turbidity from kaolin suspension.

\subsubsection{Flocculation Activity}

Kaolin suspension was prepared using $0.7 \mathrm{~g}$ kaolin clay in 1 liter of tap water (turbidity $900 \pm 10 \mathrm{NTU}$ ). Each Jar contained $500 \mathrm{ml}$ kaolin suspension was added with $1 \%$ supernatant $(\mathrm{v} / \mathrm{v})$. The jar apparatus was then operated at a speed of $120 \mathrm{rpm}$ with 40 minutes mixing time and allowed to settle for 30 minutes [19]. Next, the top layer of water in each Jar was collected with a micro pipette and turbidity was measured with a portable turbidimeter 2100Q HACH, USA to measure residual turbidity. In the control experiment, $1 \%(\mathrm{v} / \mathrm{v})$ of supernatant was replaced with $1 \%(\mathrm{v} / \mathrm{v})$ of nutrient broth. The flocculating activity was calculated according to the following equation [23].

$$
\text { Flocculating activity }(\%)=\left[\frac{A-B}{A}\right] \times 100 \%
$$

where, $A$ is the initial turbidity value and $B$ is the residual turbidity after flocculation.

\section{RESULTS AND DISCUSSION}

\subsection{Myco-flocculant Production}

\subsubsection{Screening of Potential Nutrient}

Figure 1 (a) shows the flocculating activity of two coagulants for 6 days in media containing starch, sucrose, yeast extract, and malt extract. Starch, sucrose, and yeast extract were not favourable for L. squarrosulus and S. obclavatum growth, while the production of coagulants was relatively low when carbon and nitrogen sources were used separately. 

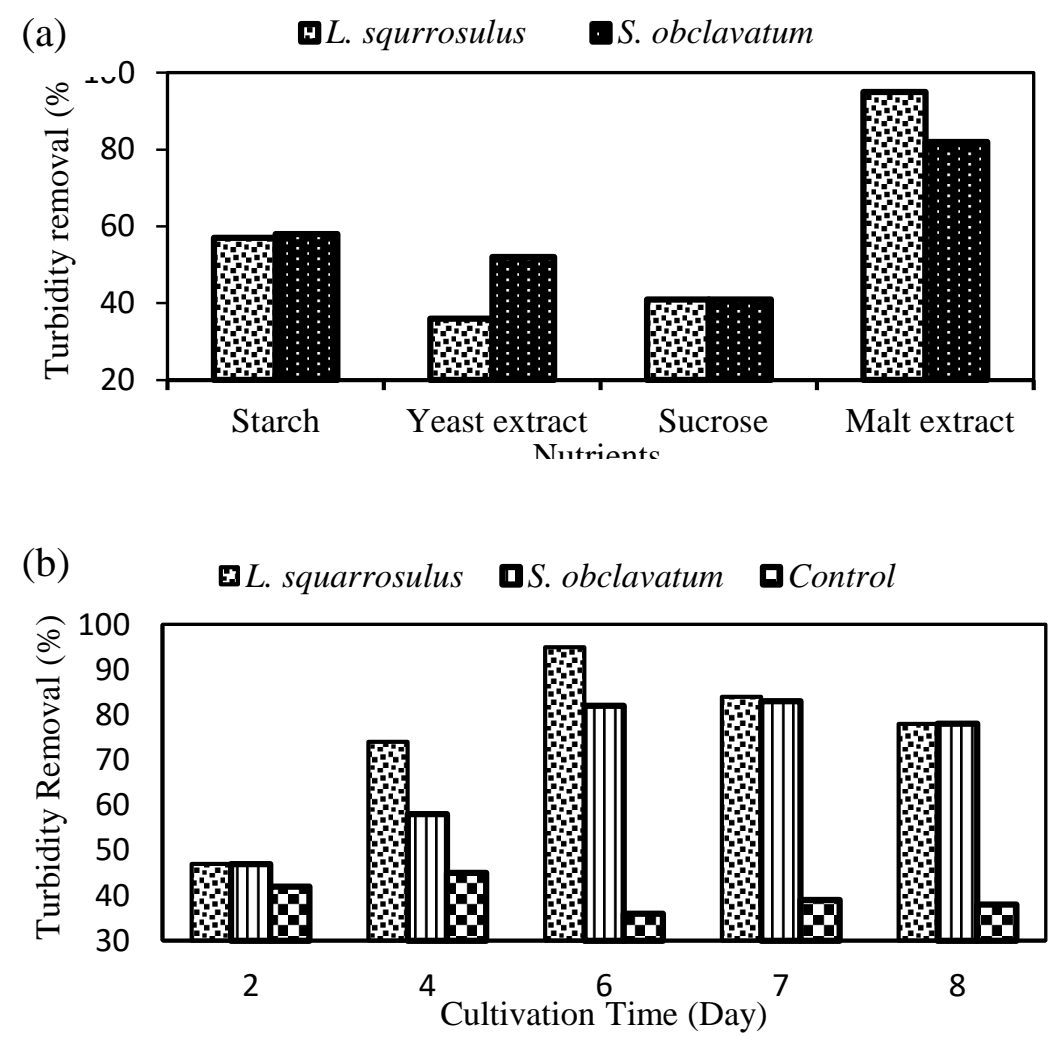

Fig. 1: The effects of nutrient and cultivation time on myco-flocculant production.

a) Screening of potential nutrient, b) Culture time with malt extract.

The highest myco-flocculant production from L. squarrosulus and S. obclavatum were obtained in malt extract media. Malt extract was used as co-substrate to enhance the separation and filtration process of treated sludge by fungal growth formation [24]. Aljuboori et al. [25], reported that the highest coagulant production by Aspergillus niger was observed when the $\mathrm{C} / \mathrm{N}$ ratio increased up to $20 / 1$ with a flocculating rate of $79 \%$ respectively, but that further increase in the $\mathrm{C} / \mathrm{N}$ ratio slightly decreased the production. Figure 1 (b) shows the cultivation time with flocculation activity in terms of turbidity removal rate of myco-coagulants. The culture during the early stationary phase showed the highest (95\% and $82 \%$ at 6 days) flocculating rate of $L$. squarrosulus and S. obclavatum, respectively. Results showed the flocculating rate decreased slowly after 6 days, suggesting these strains may be secreting deflocculation enzymes. A similar result was reported in the cultivation of A. parasiticus [20] and B. licheniformis [26]. Consequently, a period of 6 days was chosen as the culture time for the subsequent experiments.

\subsubsection{Effect of Media Concentration, Initial pH, and Inoculum Size}

Figure 2 shows the effect of malt extract concentration on the flocculating rate of two myco-coagulants. L. squarrosulus and S. obclavatum increased myco-flocculants at $0.1 \%$ (w/v) and $0.25 \%$ concentration, respectively. The flocculating activity of two fungal strains was poor without malt extract concentration in the culture $(0 \%)$. Small growth was found from the two fungal strains without nutrients (malt extract), suggesting that the strains may not able to secrete any metabolites due to lack of growth. 


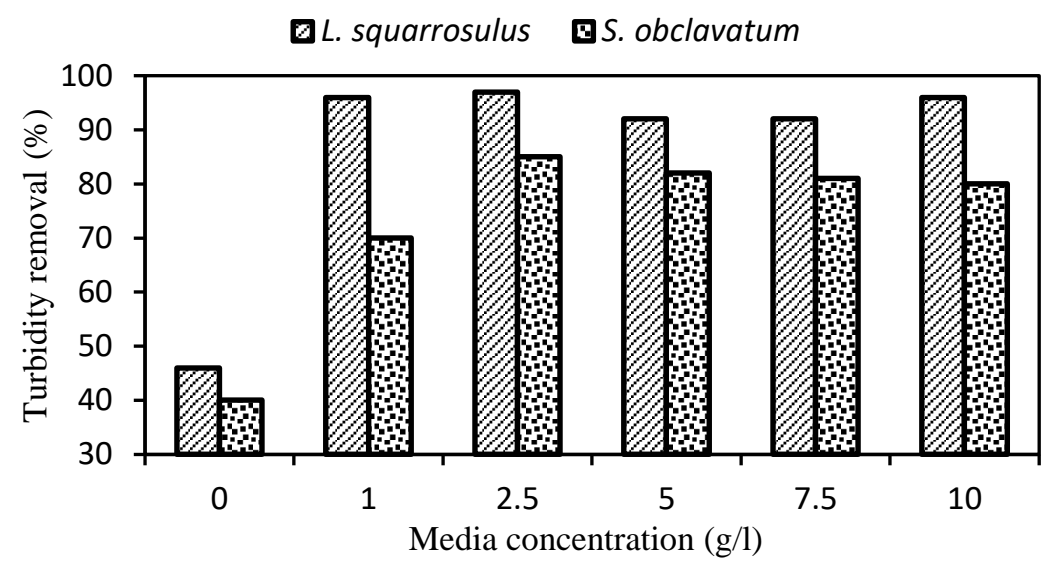

Fig. 2: Effect of media concentration of the flocculation activity on myco-flocculants.

Figure 3 shows the effect of the initial $\mathrm{pH}$ of the culture medium on bio-coagulant production. The flocculating activity increased when $\mathrm{pH}$ was varied from 5 to 7 with the maximum flocculating activity of $95 \%$. The removal rate $(77 \%)$ decreased at an alkaline $\mathrm{pH}$ (8) for both of the cultures. Salehizadeh et al. [1] investigated that the initial $\mathrm{pH}$ of the production medium influences the electric charge of the cell and oxidation-reduction potential, which in turn affects the nutrient absorption and enzymatic reaction.

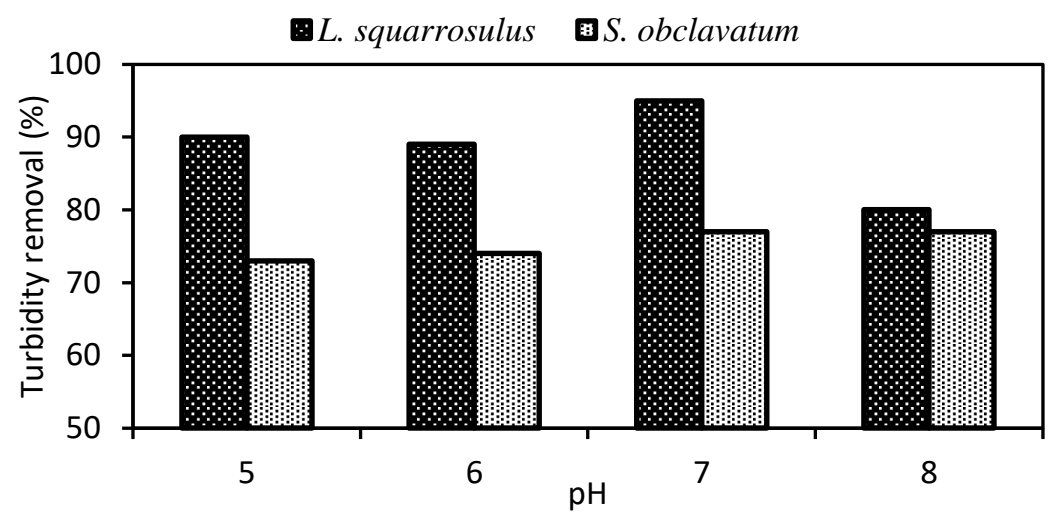

Fig. 3: Effect of the initial $\mathrm{pH}$ of the culture medium on the flocculating activity of myco-flocculants.

The flocculating rates obtained from the culture inoculated with 1 to $4 \%(\mathrm{v} / \mathrm{v})$ inoculum size of two fungal strains are shown in Fig. 4. The use of 2 to $3 \%$ of L. squarrosulus inoculum dose in production medium recorded the highest flocculating rate of $96 \%$. S. obclavatum was gradually decreased when inoculum dose was increased due to excessive overlapping of cells, resulting in inhibition of coagulant production. Aljuboori et al. [13] reported an optimal coagulant production by Aspergillus flavus at 2\% (v/v) inoculum size, whereas a higher inoculum size of $10 \%(\mathrm{v} / \mathrm{v})$ was most suitable for coagulant production by Rhizopus sp. [21] 


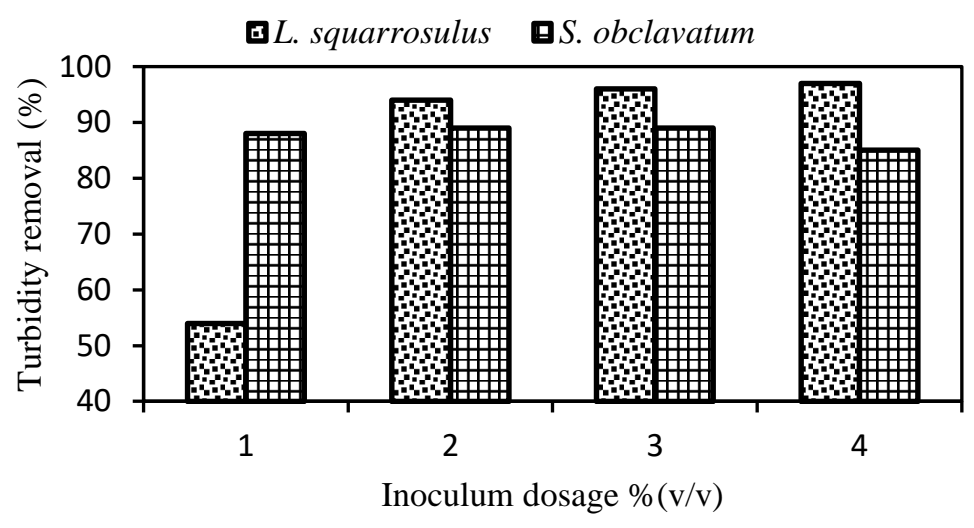

Fig. 4: Effect of inoculum dose of culture medium on myco-flocculants production.

\subsubsection{Compatible Mixed Culture}

Figure 5(A) shows ten day old single and mixed culture plates of L. squarrosulus and S. obclavatum. Figure 5(B) shows the turbidity removal (\%) of single and mixed cultures. The flocculation rate was higher at $88 \%$ of mixed culture compared to the single culture of S. obclavatum (78\%). The mixed culture showed significant growth of L. squarrosulus in the PDA plate, which indicated that the compatible mixed culture of L/S may have produced more substances to enhance flocculation to reduce turbidity compared to single $S$. obclavatum culture. Alam et al. [12] reported the fungal mixed culture of Aspergillus niger and Penicillium corylophilum was enhanced the separation process of wastewater sludge. Two strains of Rhizopus sp. produced a compound coagulant that was used to reduce turbidity of $91.1 \%$ from potato starch wastewater [21].

(A)
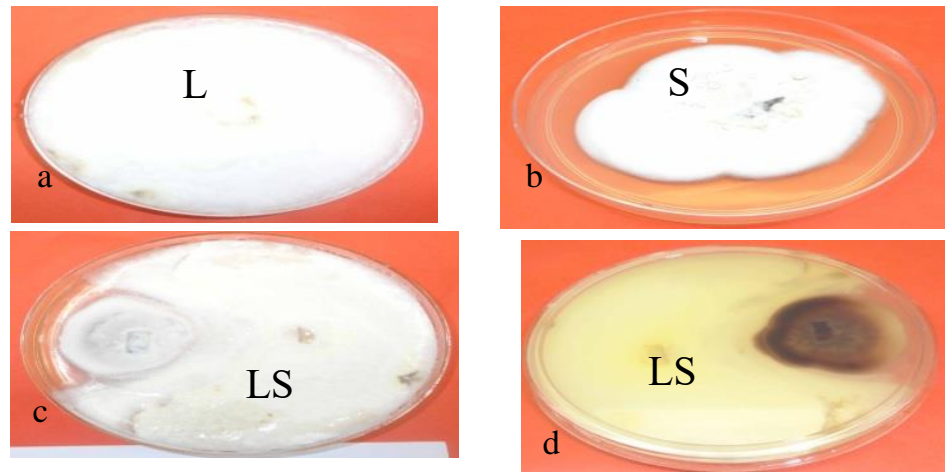

(B)

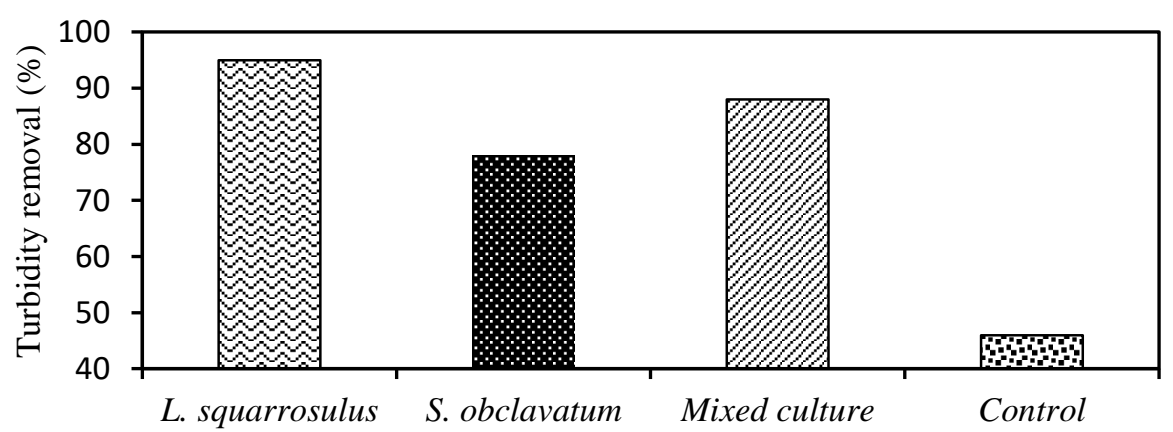

Fig. 5: Compatible mixed culture (A) L. squarrosulus (A-a), S. obclavatum (A-b), L. squarrosulus and $S$. obclavatum $(\mathrm{L} / \mathrm{S})$ front side of plate $(\mathrm{A}-\mathrm{c}), \mathrm{L} / \mathrm{S}$ reverse side of plate (B) Turbidity removal by single and compatible mixed culture. 


\subsubsection{Myco-coagulants Stability by Jar Test}

Figure 6(a) shows that L. squarrosulus was stable at a wide range, from $\mathrm{pH} 4.0$ to 8.0 and more than $90 \%$ flocculation was achieved within this range. At $\mathrm{pH} 7.0$, the turbidity removal rate was higher for both myco-coagulants and the flocculation rate decreased slowly as the $\mathrm{pH}$ increased further. The mixed culture also showed good stability at pH 7.0. Thus, these myco-coagulants are suitable to be applied at acidic and neutral conditions. This may be due to the fact that myco-flocculants show different electric charges at different $\mathrm{pH}$ levels and affect the flocculation ability of the bio-flocculant for kaolin particles [27].
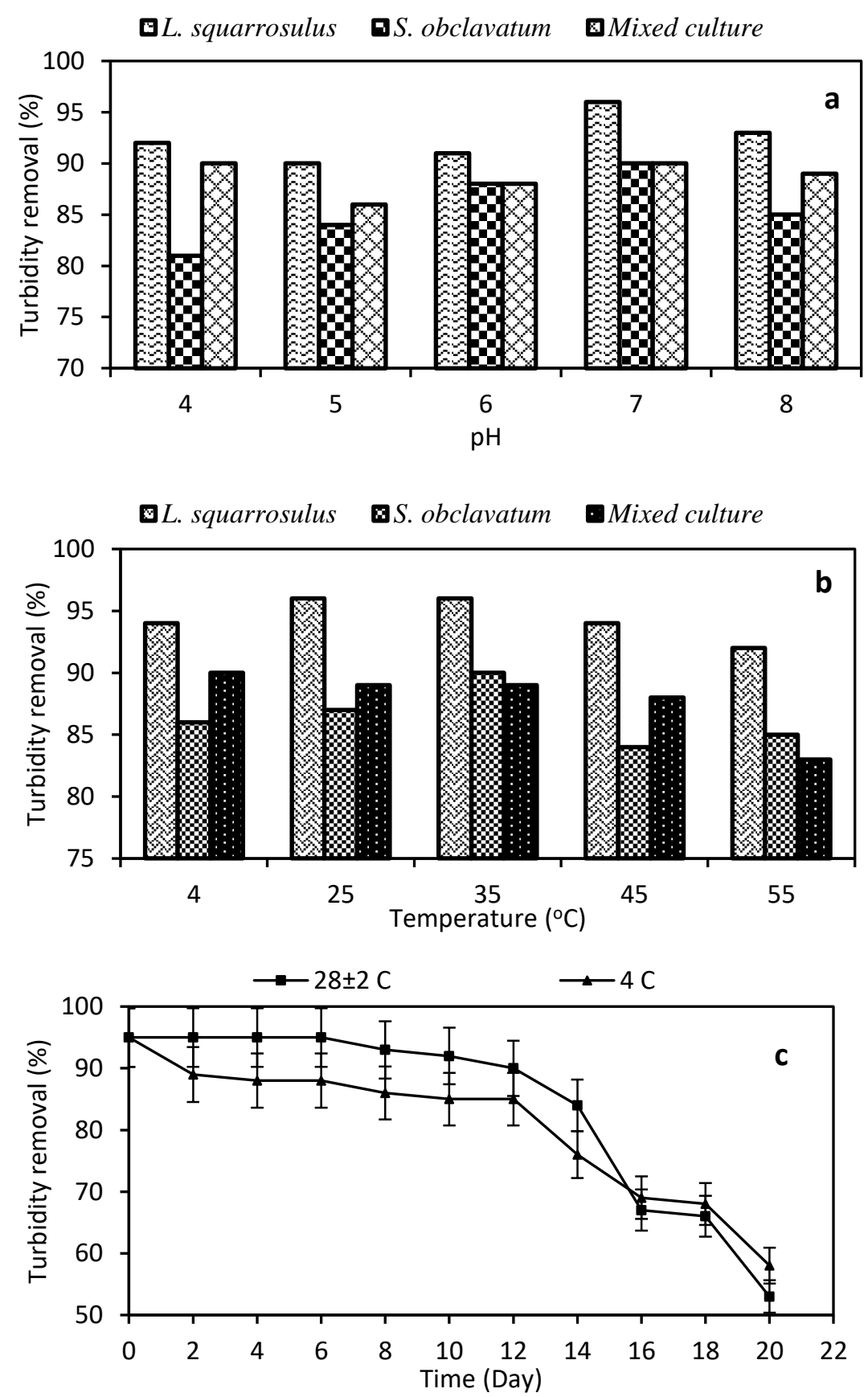

Fig. 6: Myco-flocculant stability: a) The pH stability of L. squarrosulus, S. obclavatum and mixed culture; b) Temperature stability of L. squarrosulus, S. obclavatum and mixed culture; c) Time Stability of myco-flocculant (L. squarrosulus). 
The effect of temperature on the flocculating activity of myco-flocculants was investigated (Fig. 6-b). The results showed that both myco-flocculants are fairly temperature-tolerant and had good flocculation activity at a wide range of temperatures. The flocculation ratio varied from $92 \%$ to $96 \%$ (L. squarrosulus) and $84 \%$ to $90 \%$ ( $S$. obclavatum) in the temperature range of $4{ }^{\circ} \mathrm{C}$ to $55^{\circ} \mathrm{C}$, and only begins to decrease slightly with further temperature increase from $45^{\circ} \mathrm{C}$ to $55^{\circ} \mathrm{C}$. The mixed myco-flocculant showed good stability at $4^{\circ} \mathrm{C}$, then gradually decreased in temperature range to $45^{\circ} \mathrm{C}-55^{\circ} \mathrm{C}$. The highest turbidity removal rate of $96 \%$ was observed at $25{ }^{\circ} \mathrm{C}$ and $35{ }^{\circ} \mathrm{C}$ for the $L$. squarrosulus myco-coagulant. These myco- flocculants were more stable at moderate temperatures (range $25^{\circ} \mathrm{C}$ and $35^{\circ} \mathrm{C}$ ). Similar findings were observed by Aljuboori et al. [9], on the bioflocculant produced by Aspergillus flavus with a residual flocculating activity of about $93 \%$ at temperature range from 5 to $45{ }^{\circ} \mathrm{C}$, thus indicating a thermostable bioflocculant. The result was similar to reported for the bioflocculant produced by Aspergillus parasiticus and it had moderate heat-stability [20].

Figure 6(c) shows the effect of time stability on turbidity removal rate of $L$. squarrosulus produced myco-flocculant. The highest turbidity removal $\%$ was recorded at room temperature $\left(28 \pm 2{ }^{\circ} \mathrm{C}\right)$ till 12 days then it showed decreased flocculation activity of the myco-flocculant. This may be due to the fact that the metabolites of the myco-coagulant are deactivated gradually after two weeks of storage. However, turbidity removal rate was $85 \%$ at low temperature $\left(4{ }^{\circ} \mathrm{C}\right)$ stored coagulant with 12 days. After two weeks, the flocculation activity was decreased gradually and it reached at about $50 \%$ at 20 days. This may have occurred due to the deactivation of metabolites.

\section{CONCLUSIONS}

This study shows that L. squarrosulus and S. obclavatum produced myco-flocculants that were effective in the removal of turbidity of a kaolin suspension. The optimal conditions of L. squarrosulus myco-flocculant production were malt extract concentration $0.1 \%(\mathrm{~g} / \mathrm{l})$, initial $\mathrm{pH} 7.0$ and inoculum dose $3 \%$ (v/v) for 6 day cultivation time which the flocculating activity reached above $95 \%$. The two myco-flocculants' stability indicates that they can work at different $\mathrm{pH}$ ranges between 4-8 and can be stored at room temperature $\left(25^{\circ} \mathrm{C}\right)$. Finally, both novel myco-coagulants are expected to be potential replacements of chemical coagulants and widely applied in water treatment and other industries.

\section{ACKNOWLEDGMENT}

The authors would like to express their thanks to Ministry of Higher Education (MOHE) for granting a Fundamental Research Grant Scheme (FRGS), project No. FRGS-14-109-0350 for the financial support. Thanks also to Research Management Centre (RMC), International Islamic University Malaysia for financial management and monitoring the progress of the project.

\section{REFERENCES}

[1] Salehizadeh H, Shojaosadati SA. (2001) Extracellular biopolymeric coagulants: recent trends and biotechnological importance. Biotechnology Advances, 19(5):371-385.

[2] You Y, Ren N, Wang A, Ma F, Gao L, Peng Y, Lee D. (2008) Use of waste fermenting liquor to produce bioflocculants with isolated strains. International Journal of Hydrogen Energy, 33(13):3295-3301. 
[3] Prakash N B, Sockan V, Jayakaran P. (2014) Waste water treatment by coagulation and flocculation. International J. of Engineering Science and Innovative Technology, 3(2):479484.

[4] Yan C, Le L, Yan-Hong G, Zi-Wen X. (2013) Characteristics analysis of different coagulants in the removal of organic matters of raw yellow river water. Information Technology Journal, 12(20):5746-5750.

[5] Ruden C. (2004) Acrylamide and cancer risk- expert risk assessments and the public debate. Food and Chemical Toxicology, 42(3):335-349.

[6] Yang YN, Ren N, Xue JM, Yang J, Rong BL. (2007) Mutation effect of MeV protons on bioflocculant bacteria Bacillus cereus. Nuclear Instruments and Methods in Physics Research Section B, 262:220-224.

[7] Li Z, Zhong S, Lei HY, Chen RW, Yu Q, Li HL. (2009) Production of a novel bioflocculant by Bacillus licheniformis X14 and its application to low temperature drinking water treatment. Bioresource Technology,100(14):3650-3656.

[8] Gong WX, Wang SG, Sun XF, Liu XW, Yue QY, Gao BY. (2008) Bioflocculant production by culture of Serratia ficaria and its application in wastewater treatment. Bioresource Technology, 99(11):4668-4674.

[9] Aljuboori AH, Idris A, Al-joubory HH, Uemura Y, Abubakar BI. (2015) Flocculation behavior and mechanism of bioflocculant produced by Aspergillus flavus. Journal of Environmental Management. 150:466-71.

[10] Gao Q, Zhu XH, Mu J, Zhang Y, Dong XW. (2009) Using Ruditapes philippinarum conglutination mud to produce bioflocculant and its applications in wastewater treatment. Bioresource Technology, 100(21):4996-5001.

[11] Subramanian SB, Yan S, Tyagi RD, Surampalli RY. (2008) A new, pellet-forming fungal strain: its isolation, molecular identification, and performance for simultaneous sludge-solids reduction, flocculation, and dewatering. Water Environment Research, 80(9):840-852.

[12] Alam MZ, Fakhru'l-Razi A. (2003) Enhanced settleability and dewaterability of fungal treated domestic wastewater sludge by liquid state bioconversion process. Water research, 37(5):1118-1124.

[13] Aljuboori AH, Idris A, Abdullah N, Mohamad R. (2013) Production and characterization of a bioflocculant produced by Aspergillus flavus. Bioresource Technology,12:489-493.

[14] More TT, Yadav JS, Yan S, Tyagi RD, Surampalli RY. (2014) Extracellular polymeric substances of bacteria and their potential environmental applications. Journal of Environmental Management, 144:1-25.

[15] Okaiyeto K, Nwodo UU, Mabinya LV, Okoh AI. (2015) Bacillus toyonensis strain AEMREG6, a bacterium isolated from South African marine environment sediment samples produces a glycoprotein bioflocculant. Molecules, 20(3):5239-5259.

[16] Subramanian SB, Yan S, Tyagi RD, Surampalli RY. (2010) Extracellular polymeric substances (EPS) producing bacterial strains of municipal wastewater sludge: isolation, molecular identification, EPS characterization and performance for sludge settling and dewatering. Water Research, 44(7):2253-2266.

[17] Nwodo UU, Okoh AI. (2013) Characterization and flocculation properties of biopolymeric flocculant (Glycosaminoglycan) produced by Cellulomonas sp. Okoh. Journal of Applied Microbiology, 114(5):1325-37.

[18] Jebun N, Al-Mamun A, Alam MZ, Karim MI, Raus RA. (2015) Evaluation of entrapment potentiality and turbidity removal efficiency of filamentous fungi. Jurnal Teknologi, 77(24):23-28.

[19] Jebun N, Al-Mamun A, Alam MZ, Raus RA. (2016) Fungal Flocculants to Reduce Turbidity of River Water. ARPN Journal of Engineering and Applied Sciences, 11(6):4094-4099.

[20] Deng S, Yu G, Ting Y. (2005) Production of a bioflocculant by Aspergillus parasiticus and its application in dye removal. Colloids and Surfaces B: Biointerfaces, 44(4):179-186.

[21] Pu SY, Qin LL, Che JP, Zhang BR, Xu M. (2014) Preparation and application of a novel bioflocculant by two strains of Rhizopus sp. using potato starch wastewater as nutrilite. Bioresource Technology, 162:184-91. 
[22] Luvuyo N, Nwodo UU, Mabinya LV, Okoh AI. (2013) Studies on bioflocculant production by a mixed culture of Methylobacterium sp. Obi and Actinobacterium sp. Mayor. BMC biotechnology, 13(62):1-7.

[23] Kurane R, Hatamochi K, Kakuno T, Kiyohara M, Hirano M, Taniguchi Y. (1994) Production of a bioflocculant by Rhodococcus erythropolis S-1 grown on alcohols. Bioscience, Biotechnology, and Biochemistry, 58(2):428-429.

[24] Alam M, Fakhru'l-Razi A, Molla AH. (2004) Evaluation of fungal potentiality for bioconversion of domestic wastewater sludge. Journal of Environmental Sciences, 16(1):132137.

[25] Aljuboori AH, Uemura Y, Osman NB, Yusup S. (2014) Production of a bioflocculant from Aspergillus niger using palm oil mill effluent as carbon source. Bioresource Technology, 171:66-70.

[26] Shih I, Van Y, Yeh L, Lin H, Chang Y. (2001) Production of a biopolymer flocculant from Bacillus licheniformis and its flocculation properties. Bioresource Technology, 78(3):267272.

[27] Pan Y, Shi B, Zhang Y. (2009) Research on flocculation property of bioflocculant PG.a21 Ca. Modern Applied Science, 3(6):106 - 112. 